\title{
Community Satisfaction on The Performance of Public Services in Lampung Tengah
}

\author{
Dedy Hermawan ${ }^{1}$, Robi Cahyadi Kurniawan ${ }^{2}$, Rudi Wijaya ${ }^{3}$, Chaidir Ali ${ }^{4}$ \\ \{dedy.hermawan@fisip.unila.ac.id ${ }^{1}$, robi.cahyadi@fisip.unila.ac.id ${ }^{2}$ \} \\ FISIP University of Lampung ${ }^{1}$, FH University of Lampung ${ }^{2}$
}

\begin{abstract}
Public service in Indonesia is still a big homework in order to realize excellent and optimal service. The standard of public service for the bureaucracy, especially in the regions is still limited to slogans without implementation in the performance area. Research on community satisfaction with the performance of public services in Lampung Tengah district was conducted in September-November 2018, involving 384 respondents using quantitative methods through surveys. The results of the study show that education and health services that are basic services and compulsory local governments are still in an unfavorable dimension or range. Need to improve on a large scale so that public services in Lampung Tengah Regency can meet good standards.
\end{abstract}

Keywords: public service; community satisfaction; Lampung Tengah district

\section{Introduction}

The division of government affairs in accordance with Law Number 23 Year 2014 consists of: (1) absolute governance, namely government affairs that are fully under the authority of the Central Government; (2) general government governance, namely government affairs which are under the authority of the President as head of government; and (3) concurrent government affairs, namely government affairs that are divided between the Central and Provincial and District / city governments and become the basis for the implementation of regional autonomy and are based on the principles of accountability, efficiency, and externalities, as well as national strategic interests. Concurrent government affairs which are the authority of the region consist of compulsory government affairs and elected government affairs. One of the authorities of the regional government at the level of the City / Regency relating to government affairs must comprise government affairs relating to services which include: (1) education; (2) health; (3) public works and spatial planning; (4) public housing and residential areas; (5) peace, public order and community protection; and (6) social.

The division of authority relating to government affairs must provide consequences for the City / Regency government to provide services to the community optimally. The development of authority relating to mandatory affairs services is inseparable from the enactment of regional autonomy which provides regional freedom in managing its finances both from regional revenues and government assistance. center. On the other hand, the decentralization of mandatory services to the City / District governments is expected to be able to improve the welfare of the community and increase public trust in the government. Negative highlights of the services provided by local governments to the public should be used as a basis for efforts to improve bureaucracy and public service governance. Complicated bureaucracy, unpleasant 
behavior, inadequate facilities, and various levies other than provisions are the triggers of public dissatisfaction with the services provided by the government. Efforts to eliminate negative assumptions that arise in the community have been carried out both in the form of rewards (rewards) and punishment (punishment) for implementing public services. Increased facilities and infrastructure facilities have been staged so that services can be better.

\section{Method}

According to the Big Indonesian Dictionary, service has three meanings: (1) subject or method of service; (2) efforts to serve the needs of others by obtaining compensation (money); (3) facilities provided in connection with the sale and purchase of goods or services. Understanding service according to the American Marketing Association as quoted by Donald (1984) in Sinambela (2011) that service is basically an activity or benefit offered by a party to another party and is essentially intangible and does not result in ownership of something, process production may also not be associated with a physical product. Whereas according to Lovelock (1991) in Sinambela (2011), service is a product that is intangible, lasts a moment and is felt or experienced. That is, service is a product that has no form or form so that there is no form that can be owned, and lasts a moment or is not durable, but is experienced and can be felt by the recipient of the service. Davidow in Waluyo (2007) states that services are things that if applied to a product will increase the power or value of the customer. Furthermore, he stated that good service requires very good service instructors. The most important thing is to make everyone in the organization quality-oriented. Meanwhile, the public term comes from English which means general, customer, country. Public Indonesian has become a public standard which means public, people, and crowded with the equivalent word is praja which means people so that the term pamong praja is born which means the government serves the interests of all people (Badudu and Zain, 2001).

Public service by Roth (1987) in Istianto (2009) is defined as any service available to the public whether it is provided or privately (as is a restaurant meal). Mccording to Law - Law Number 25 Year 2009 on the Public Service, Chapter I Section 1 Paragraph 1, which referred to the public service is an activity or series of activities in order to meet the needs of the service in accordance with the laws of every citizen and resident in the goods, services, and or administrative services provided by public service providers. Following the above understanding, Ratminto and Atik (2007) in Hardiansyah (2011) define public services or public services as all forms of services, both in the form of public goods and public services which in principle are the responsibility and implemented by government agencies in the central, regional, and within the State-Owned Enterprises or Regional Owned Enterprises in an effort to fulfill the needs of the Customer and in the context of implementing the provisions of the legislation.

Public services are related to services that fall into the category of the public sector, not the private sector. The service is carried out by the central government, regional government, and BUMN / BUMD. The three components that deal with the public sector provide public services such as health, education, security and order, social assistance, and broadcasting (Vilson (1993) in Nurcholis (2007)). Every implementation of public services must have service standards as a guarantee of certainty for the giver in the implementation of their duties and functions and for service recipients in the application process. Service standards are a standardized measure in the implementation of public services as a guideline that must be 
adhered to and carried out by service providers and serve as guidelines for service recipients in the process of submitting applications, as well as controls for customers and / or service recipients for the performance of service providers (Hardiansyah, 2011).

\subsection{Quality of Public Services}

Service quality is closely related to systematic and comprehensive services better known as the concept of excellent service. Excellent service is (Rahmayanty, 2010):

1. Excellent service and exceeding customer expectations;

2. Services that have distinctive qualities;

3. Services with high quality standards and always keep abreast of customer needs at all times, consistently and accurately (reliably);

4. Services that meet the practical needs and emotional needs of customers.

The concept of service quality can be understood through customer behavior, which is a behavior played by customers in searching for, buying use, and evaluate a product or service that is expected to satisfy their needs. According to Ibrahim (2008) the quality of public services is a dynamic condition that relates to products, services, people, processes, and the environment where the assessment of its quality is determined at the time the service is delivered. The public sector performance measurement system is a system that aims to help public managers assess the achievement of a strategy through financial and non-financial measurement tools. The performance measurement system can be used as an organizational control tool, because performance measurement is strengthened by setting reward and punishment systems. Local government performance measurement is carried out to fulfill three objectives (Mardiasmo, 2002: 121), namely:

1. Improve government performance

2. Helps allocate resources and make decisions

3. Realizing public accountability and improving institutional communication. In general, the objectives of a performance measurement system are:

1. To communicate the strategy better (top down and bottom up);

2. To measure financial and non-financial performance in a balanced manner so that the development of strategy achievement can be traced;

3. To accommodate the understanding of the interests of middle and lower level managers and motivate to achieve goal congruent;

4. As a tool to achieve satisfaction based on individual approaches and rational collective abilities.

\subsection{Community Satisfaction}

According to Mendelsohn (1998) there are 2 advantages for business entities with community satisfaction, namely: (1) keeping customers cheaper than buying new ones; and (2) increasing competition in the form of products, organizations, and distribution of outlets means fierce pressure for consumers. Consumer satisfaction is a viable strategy to maintain market share in competition. To measure community satisfaction, an attribute that is used is about how people value a product or service that is reviewed from customer point of view. According to Frederik Mote (2008), community satisfaction can be measured through satisfaction-forming attributes consisting of:

1. Value to price relationship. The relationship between the price set by the business entity to be paid with the value / benefits obtained by the community 
2. Product value, is an assessment of the quality of the product or service produced by a business entity.

3. Product benefits, are benefits obtained by the community from consuming products produced by business entities.

4. Product features, are certain characteristics or characteristics that support the basic functions of a product so that it is different from the products offered by competitors.

5. Product design, is a process for designing product appearance and function.

6. Product reliability and consistency, is the accuracy and reliability of the products produced by a business entity.

7. Range of product are services, is a type of product or service offered by a business entity.

Then the attribute related to service includes (Frederik Mote, 2 008: 20): First; Guarantee or warranty, is a guarantee or guarantee given by a business entity and is expected to satisfy the community. Second; Delivery communication, is a message or information conveyed by the business person to the community. Third; complain handling, is the attitude of the business entity in handling complaints and complaints. Fourth; Resolution of problem, is the response given by business entities to help solve community problems related to the services they receive. A attribute related to the purchase as follows (Frederik Mote, 2008: 21), first; Courtesy, is courtesy, attention and friendliness of employees. Second; Communication, is the ability of employees to communicate with the customer community. Third; Ease or convenience of acquisition, is the convenience provided by a business entity to get the product or service offered. Fourth; Company reputation, is a good reputation or not owned by a business entity in serving the community. Fifth; Company competence, whether or not the ability of a business entity to serve the community.

\section{Research Methods}

The study used a qualitative approach with Likert scale measurements. Likert scale is a psychometric scale that is commonly used in questionnaires (questionnaires), and is the scale most widely used in research in the form of surveys. This method was developed by Rensis Likert. Likert scale is a scale that can be used to measure attitudes, opinions, and perceptions of a person or group of people towards a type of public service. On the Likert scale respondents were asked to determine their level of agreement with a statement by choosing one of the available options. The population in the study in Central Lampung Regency consisted of all households that have been permanently domiciled in the Central Lampung Regency area. The number of households in Central Lampung Regency in 2016 was 339,319 households.

Respondents in this survey were selected using a purposive sampling technique. According to Sugiyono (2010) purposive sampling is a technique for determining research samples with certain considerations aimed at making the data obtained later more representative. Using formulas sample from Krejcie and Morgan , then obtained the sample of this study amounted to 384 respondents. The elements studied are as follows: 


\begin{tabular}{|c|l|c|}
\hline No. & \multicolumn{1}{|c|}{ Element of satisfaction } & Element Value \\
\hline $\mathbf{1}$ & Requirements & $\mathrm{A}$ \\
$\mathbf{2}$ & Systems, mechanisms and procedures & $\mathrm{B}$ \\
$\mathbf{3}$ & Settlement time & $\mathrm{C}$ \\
$\mathbf{4}$ & Fees / Rates & $\mathrm{D}$ \\
$\mathbf{5}$ & Product type of service specifications & $\mathrm{E}$ \\
$\mathbf{6}$ & Implementing competencies & $\mathrm{F}$ \\
$\mathbf{7}$ & Implementing behavior & $\mathrm{G}$ \\
$\mathbf{8}$ & Handling complaints, suggestions, and input & $\mathrm{H}$ \\
$\mathbf{9}$ & Facilities and infrastructure & $\mathrm{I}$ \\
\hline
\end{tabular}

The range of values in this study are as follows:

\begin{tabular}{|c|c|c|c|c|}
\hline $\begin{array}{c}\text { Perception } \\
\text { Value }\end{array}$ & $\begin{array}{c}\text { Interval Value } \\
(\mathbf{N I})\end{array}$ & $\begin{array}{c}\text { Conversion } \\
\text { Interval Value } \\
\text { (NIK) }\end{array}$ & $\begin{array}{c}\text { Service } \\
\text { Quality (x) }\end{array}$ & $\begin{array}{c}\text { Service Unit } \\
\text { Performance } \\
\text { (y) }\end{array}$ \\
\hline $\mathbf{1}$ & $1.00-2.5996$ & $25.00-64.99$ & $\mathrm{D}$ & Not good \\
\hline $\mathbf{2}$ & $2.60-3,064$ & $65.00-76.60$ & $\mathrm{C}$ & Not good \\
\hline $\mathbf{3}$ & $3.0644-3,532$ & $76,61-88,30$ & $\mathrm{~B}$ & Well \\
\hline $\mathbf{4}$ & $3,5324-4,00$ & $88.31-100$ & $\mathrm{~A}$ & Very good \\
\hline
\end{tabular}

\section{Results and Discussion}

The survey was carried out with a total sample of 384 people with predetermined criteria. Sampling was done randomly by accidental sampling method. The majority of respondents who were used as community satisfaction surveys were mostly young people aged 21-30 years as much as $41 \%$ or as many as 159 respondents from 384 respondents. The age of $>50$ years is 68 people (18\%), age $31-40$ years as many as 62 people (16\%), age $41-50$ years as many as 48 people $(13 \%)$, and the remaining $<20$ years as many as 47 people $(12 \%)$ Respondents in this study were not only people who directly enjoyed the services provided by the Central Lampung Regency Government, but also people who had direct involvement / knowledge in helping their relatives to enjoy the services provided.

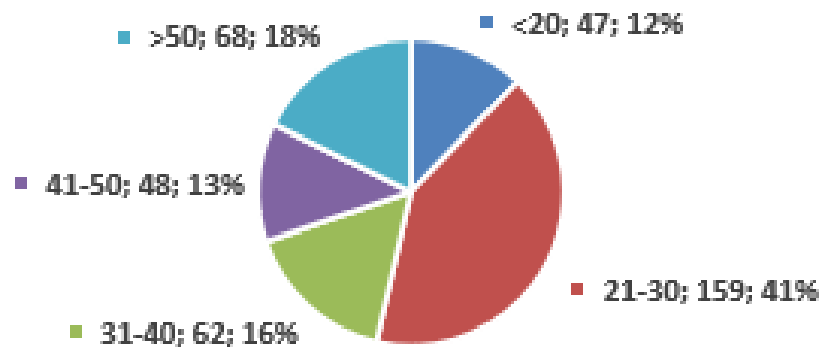

Fig 1. Distribution of age of respondents 
Random sampling using the accidental sampling method . Respondents in this survey by sex were 215 men or $56 \%$ and the rest were 169 women or $44 \%$.

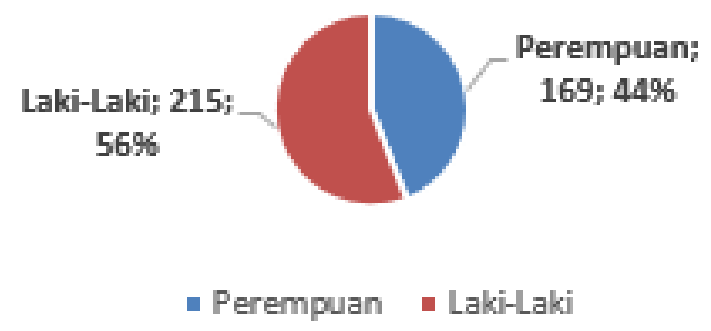

Fig 2. Distribution of respondents by sex

Respondents based on the level of education they have obtained are the results that high school / equivalent is the highest level of education that has been taken by the respondents with 194 people or $51 \%$ of the total respondents as many as 384 people. The respondents who have taken tertiary education (diploma, S-1, and S-2) total 94 people or $24 \%$ of the total respondents as many as 284 people.

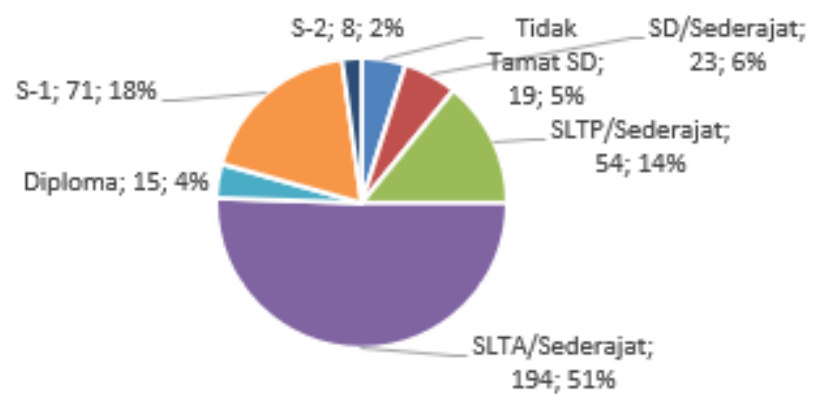

Fig 3. Distribution of respondents based on education levels

Based on the main types of work currently undertaken, respondents with other types of work amounted to 186 people or $48 \%$ of the total respondents as many as 384 people. The other types of work are dominated by the type of work of farmers. This is in accordance with the agrarian area of Central Lampung Regency which is dominated by agriculture and plantation sectors. As for the number of respondents with the main types of private employment as many as 113 people (29\%), Polri as many as 38 people (10\%), PNS as many as 27 people (7\%), and the rest entrepreneurs as many as 21 people $(6 \%)$.

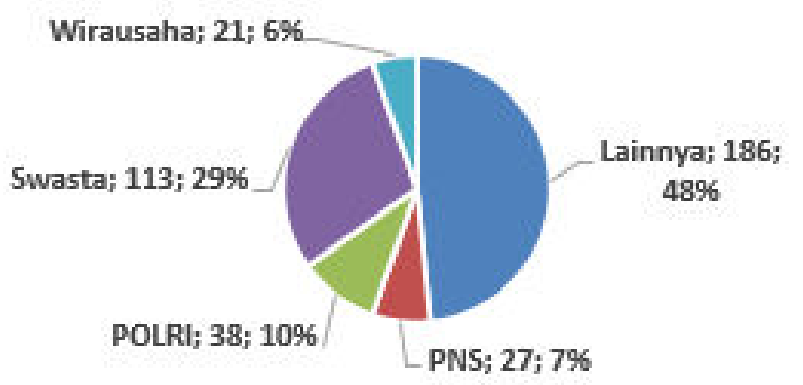


Fig 4. Distribution of respondents based on the main types of work

Lampung Tengah Regency has a Regional Minimum Wage of Rp2,083,640.38. Based on the average income of respondents in a month, the number of respondents who have an average income above the UMR is 163 people or as much as $42 \%$ of the total respondents as many as 384 people. The rest are respondents who have an average income below the Central Lampung Regency UMR of 221 people or $58 \%$ of the total respondents as many as 384 people. Income of respondents will describe their ability to fulfill their basic needs before meeting other needs. In this case, there are still many respondents who are only oriented to meeting basic life needs.

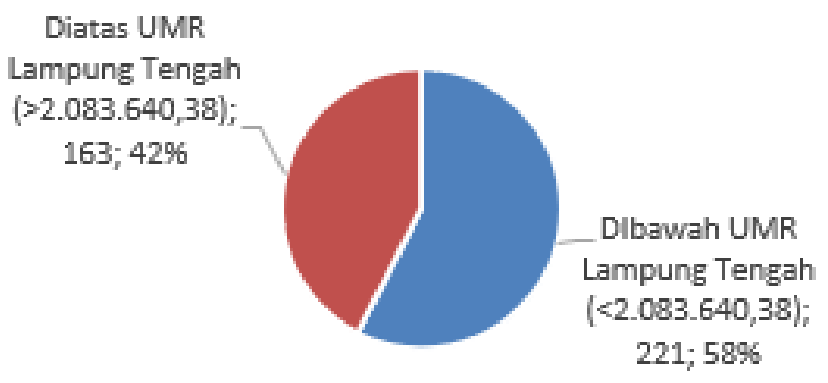

Fig 5. Distribution of respondents based on average monthly income

\subsection{Performance of Education Services in Lampung Tengah}

The results of processing data based on the answers of each respondent in the element of education services indicate that all elements of education services in Central Lampung Regency are still not optimal. More detailed results can be presented in the following table.

Table 1. Table of Performance of Elements of Educational Services

\begin{tabular}{|c|l|c|c|c|}
\hline No. & \multicolumn{1}{|c|}{$\begin{array}{c}\text { Elements of Educational } \\
\text { Services }\end{array}$} & Average value & IKM & Performance \\
\hline 1 & element of requirements & 2.57 & 64.26 & Not good \\
\hline 2 & $\begin{array}{l}\text { elements of systems, } \\
\text { mechanisms and procedures }\end{array}$ & 2.67 & 66.80 & Not good \\
\hline 3 & element of completion time & 2.54 & 63,61 & Not good \\
\hline 4 & element of cost / tariff & 2.54 & 63.41 & Not good \\
\hline 5 & $\begin{array}{l}\text { product element specification } \\
\text { type of service }\end{array}$ & 2.59 & 64,78 & Not good \\
\hline 6 & $\begin{array}{l}\text { element of implementing } \\
\text { competence }\end{array}$ & 2.89 & 72.20 & Not good \\
\hline 7 & $\begin{array}{l}\text { elements of implementing } \\
\text { behavior }\end{array}$ & 2.93 & 73,18 & Not good \\
\hline 8 & $\begin{array}{l}\text { Elements of Complaint } \\
\text { Handling, Suggestions and }\end{array}$ & 2.28 & 57.10 & Not good \\
\hline
\end{tabular}




\begin{tabular}{|c|l|c|c|c|}
\hline & Feedback & & & \\
\hline 9 & $\begin{array}{l}\text { elements of facilities and } \\
\text { infrastructure }\end{array}$ & 2.75 & 68.75 & Not good \\
\hline
\end{tabular}

Based on the table above, it can be seen that the elements of complaint handling, advice and input are the lowest value elements that reach 57.10 or are in poor performance. While the highest achievement was found in the behavioral elements of education service implementers which reached 73.18 or in the poor category. Efforts to improve every element in education services are prioritized in areas that are in a bad condition. There are 5 elements from 9 elements which are considered to have poor performance. To assess the satisfaction of education services as a whole, data processing is carried out (appendix II). The results show that the performance value of education services in Central Lampung Regency is in position C or in a poor category. More complete results can be seen in this table.

Table 2 . Table of Education Service Performance in Lampung Tengah Regency

\begin{tabular}{|c|c|c|c|c|c|c|c|c|c|}
\hline \multirow{2}{*}{ Ket } & \multicolumn{9}{|c|}{ Element } \\
\hline & 1 & 2 & 3 & 4 & 5 & 6 & 7 & 8 & 9 \\
\hline $\begin{array}{c}\sum \text { Value / } \\
\text { Element }\end{array}$ & 987 & 1026 & 977 & 974 & 995 & 1109 & 1124 & 877 & 1056 \\
\hline NRR / element & 2.57 & 2.67 & 2.54 & 2.54 & 2.59 & 2.89 & 2.93 & 2.28 & 2.75 \\
\hline $\begin{array}{c}\text { Weighted NRR / } \\
\text { element }\end{array}$ & 0.29 & 0.30 & 0.28 & 0.28 & 0.29 & 0.32 & 0.33 & 0.25 & 0.31 \\
\hline $\begin{array}{l}\sum \text { Weighted } \\
\text { IKM NRR }\end{array}$ & \multicolumn{9}{|c|}{2.64} \\
\hline IKM Education & \multicolumn{9}{|c|}{66.00} \\
\hline $\begin{array}{l}\text { Quality of } \\
\text { Education } \\
\text { Services }\end{array}$ & \multicolumn{9}{|c|}{ C } \\
\hline $\begin{array}{l}\text { Educational } \\
\text { Service } \\
\text { Performance }\end{array}$ & \multicolumn{9}{|c|}{ Not good } \\
\hline
\end{tabular}

The results above are in line with the performance of each element of educational services that shows unfavorable conditions. By paying attention to the results of the average value of each element, all elements in education services must be increased to be more than the current achievement $(>3)$. However, in the short term the handling of the five elements is more equated so that it can improve its performance. The five elements that become the priority handling scale are elements of requirements, elements of completion time, cost / tariff elements, product elements, type of service specifications, elements of Complaint Handling, Suggestions and Feedback. 


\subsection{Performance of Health Services in Lampung Tengah}

The results of processing data based on the answers of each respondent in the element of health services indicate that all elements of health services in Central Lampung Regency are still not optimal. More detailed results can be presented in the following table.

Table 3. Table of Performance Elements of Health Services

\begin{tabular}{|c|l|c|c|c|}
\hline No. & Elements of Health Services & Average value & IKM & Performance \\
\hline 1 & element of requirements & 3.06 & 76,56 & Not good \\
\hline 2 & $\begin{array}{l}\text { elements of systems, } \\
\text { mechanisms and procedures }\end{array}$ & 3.05 & 76,24 & Not good \\
\hline 3 & element of completion time & 2.87 & 71.81 & Not good \\
\hline 4 & element of cost / tariff & 2.17 & 54.30 & Not good \\
\hline 5 & $\begin{array}{l}\text { product element specification } \\
\text { type of service }\end{array}$ & 3.06 & 76,56 & Not good \\
\hline 6 & $\begin{array}{l}\text { element of implementing } \\
\text { competence }\end{array}$ & 3.18 & 79,56 & Well \\
\hline 7 & $\begin{array}{l}\text { elements of implementing } \\
\text { behavior }\end{array}$ & 3.13 & 78,19 & Not good \\
\hline 8 & $\begin{array}{l}\text { Elements of Complaint } \\
\text { Handling, Suggestions and } \\
\text { Feedback }\end{array}$ & 2.92 & 81,18 & Well \\
\hline 9 & $\begin{array}{l}\text { elements of facilities and } \\
\text { infrastructure }\end{array}$ & 3.25 & 73.05 & \\
\hline
\end{tabular}

The condition of health services for each element in Central Lampung Regency is still better compared to education services. Based on the table above, it can be seen that the element of cost / tariff for health services is the element with the lowest value reaching 54.30 or in poor performance. While the highest achievement was found in the elements of health service facilities and infrastructure which reached 81.18 or in the good category. Other categories that are well categorized include elements of implementing competence and implementing behavior. Even though the categories are not good, the three services that approach good categories include elements of requirements, elements of the system, mechanisms, and procedures, and elements of product specifications of the type of service. Efforts to improve every element in education services are prioritized in areas that are in a bad condition.

To assess overall health service satisfaction, data processing is carried out (appendix II). The results show that the value of the performance of health services in Central Lampung Regency is in position $\mathrm{C}$ or in a poor category. More complete results can be seen in the following table. 
Table 4. Table of Performance of Health Services in Central Lampung Regency

\begin{tabular}{|c|c|c|c|c|c|c|c|c|c|}
\hline \multirow{2}{*}{ Ket } & \multicolumn{9}{|c|}{ Element } \\
\hline & 1 & 2 & 3 & 4 & 5 & 6 & 7 & 8 & 9 \\
\hline $\begin{array}{l}\sum \text { Value / } \\
\text { Element }\end{array}$ & 1176 & 1171 & 1103 & 834 & 1176 & 1222 & 1201 & 1122 & 1247 \\
\hline NRR / element & 3.06 & 3.05 & 2.87 & 2.17 & 3.06 & 3.18 & 3.13 & 2.92 & 3.25 \\
\hline $\begin{array}{c}\text { Weighted NRR } \\
\text { / element }\end{array}$ & 0.34 & 0.34 & 0.32 & 0.24 & 0.34 & 0.35 & 0.35 & 0.32 & 0.36 \\
\hline $\begin{array}{l}\sum \text { Weighted } \\
\text { IKM NRR }\end{array}$ & \multicolumn{9}{|c|}{2.97} \\
\hline IKM Health & \multicolumn{9}{|c|}{74.15} \\
\hline $\begin{array}{c}\text { Quality of } \\
\text { Health Services }\end{array}$ & \multicolumn{9}{|c|}{$\mathbf{C}$} \\
\hline $\begin{array}{c}\text { Health Service } \\
\text { Performance }\end{array}$ & \multicolumn{9}{|c|}{ Not good } \\
\hline
\end{tabular}

The results above are in line with the performance of each element of educational services that shows conditions that are close to good conditions. By paying attention to the results, the average value of each element means that all elements in health services must be increased to be more than the current achievement $(>3)$.However, in the short term the handling of the tariff / cost element is more preferable in order to increase its performance. Furthermore, handling the categorical elements is not good enough to do. Efforts to improve health services into good categories can be done more easily when compared to education services.

\subsection{Performance of Education and Health Services in Lampung Tengah}

The results of processing data based on the answers of each respondent on the elements of education and health services indicate that all elements of service in Central Lampung Regency are still not optimal. More detailed results can be presented in the following table.

Table 5. Table of Performance Elements of Central Lampung Regency Services

\begin{tabular}{|c|l|c|c|c|}
\hline No. & \multicolumn{1}{|c|}{ Service Elements } & Average value & IKM & Performance \\
\hline 1 & element of requirements & 2.82 & 70.41 & Not good \\
\hline 2 & $\begin{array}{l}\text { elements of systems, } \\
\text { mechanisms and procedures }\end{array}$ & 2.86 & 71.52 & Not good \\
\hline 3 & element of completion time & 2.71 & 67,71 & Not good \\
\hline 4 & element of cost / tariff & 2.35 & 58.85 & Not good \\
\hline 5 & $\begin{array}{l}\text { product element } \\
\text { specification type of service }\end{array}$ & 2.83 & 70,67 & Not good \\
\hline 6 & element of implementing & 3.04 & 75.88 & Not good \\
\hline
\end{tabular}




\begin{tabular}{|c|l|c|c|c|}
\hline No. & \multicolumn{1}{|c|}{ Service Elements } & Average value & IKM & Performance \\
\hline & competence & & & Not good \\
\hline 7 & $\begin{array}{l}\text { elements of implementing } \\
\text { behavior }\end{array}$ & 3.03 & 75.68 & Not good \\
\hline 8 & $\begin{array}{l}\text { Elements of Complaint } \\
\text { Handling, Suggestions and } \\
\text { Feedback }\end{array}$ & 2.60 & 65.07 & Not good \\
\hline 9 & $\begin{array}{l}\text { elements of facilities and } \\
\text { infrastructure }\end{array}$ & 3.00 & 74.97 & \\
\hline
\end{tabular}

The condition of education and health services for each element in Central Lampung Regency is mostly in the poor category. Based on the table above, it can be seen that the element of cost / tariff for health services is the element with the lowest value reaching 58.85 or in poor performance. Other non-good results are found in the elements of Complaint Handling, Suggestions and Feedback which reached a value of 65.07. The highest achievement is in the element of implementing competencies which reached 75.88 or in the poor category. Efforts to improve every element in the services provided by the Central Lampung Regency government are prioritized in areas that are not in good condition. To assess the satisfaction of service performance provided by the Central Lampung Regency government as a whole, data processing is carried out. The results show that the value of service performance in Central Lampung Regency is in position $\mathrm{C}$ with a value of 70.08 or in a poor category. More complete results can be seen in the table below.

Table 6. Table of Service Performance of Lampung Tengah Regency

\begin{tabular}{|c|c|c|c|c|c|c|c|c|c|}
\hline \multirow{2}{*}{ Ket } & \multicolumn{9}{|c|}{ Element } \\
\hline & 1 & 2 & 3 & 4 & 5 & 6 & 7 & 8 & 9 \\
\hline $\begin{array}{c}\sum \text { Value / } \\
\text { Element }\end{array}$ & 2163 & 2197 & 2080 & 1808 & 2171 & 2331 & 2325 & 1999 & 2303 \\
\hline NRR / element & 5.63 & 5.72 & 5.42 & 4.71 & 5.65 & 6.07 & 6.05 & 5,21 & 6.00 \\
\hline $\begin{array}{c}\text { Weighted NRR } \\
\text { / element }\end{array}$ & 0.31 & 0.32 & 0.30 & 0.26 & 0.31 & 0.34 & 0.34 & 0.29 & 0.33 \\
\hline $\begin{array}{l}\sum \text { Weighted } \\
\text { IKM NRR }\end{array}$ & \multicolumn{9}{|c|}{2.80} \\
\hline $\begin{array}{l}\text { Central Middle } \\
\text { District IKM }\end{array}$ & \multicolumn{9}{|c|}{70.08} \\
\hline $\begin{array}{c}\text { Quality of } \\
\text { Service } \\
\text { District. central } \\
\text { Lampung } \\
\end{array}$ & \multicolumn{9}{|c|}{$\mathbf{C}$} \\
\hline $\begin{array}{c}\text { Service } \\
\text { Performance } \\
\text { of }\end{array}$ & \multicolumn{9}{|c|}{ Not good } \\
\hline
\end{tabular}




\section{Kab. central}

\section{Lampung}

The results above are in line with the performance of each element of education and health services that shows unfavorable conditions. By paying attention to the results, the average value of each element means that all elements in health services must be increased to be more than the current achievement (>3). However, in the short term the handling of the tariff / cost element and the elements of Complaint Handling, Suggestions and Input are more equitable in order to increase its performance. Furthermore, handling the categorical elements is not good enough to do. Special attention can be given to improving education services which are in a lower position compared to health services.

\section{Conclusion}

Educational services in Central Lampung Regency are still not optimal, as seen from the performance of educational services in the poor category with an IKM value of 66.00. The five elements that become the priority handling scale are elements of requirements, elements of completion time, cost / tariff elements, product elements, type of service specifications, elements of Complaint Handling, Suggestions and Feedback. Health services in Central Lampung Regency are still not optimal, as seen from the performance of education services in the poor category with an IKM value of 74.15. However, there are several elements of service that are already in the good category, including elements of executive competence, elements of implementing behavior, and elements of facilities and infrastructure. Overall, the Community Satisfaction Index of the Central Lampung Regency government is in the poor category with an achievement of an SMI value of 70.08. The high disparity in assessment between education and health services is a major factor in the low achievement of Central Lampung Regency IKM.

Suggestions that can be conveyed in this study are; The effort to improve education services is done by increasing the service elements which are in the bad category. The five elements that become the priority handling scale are elements of requirements, elements of completion time, cost / tariff elements, product elements, specifications of service types, elements of Complaint Handling, Suggestions and Feedback. Efforts to improve health services are carried out by increasing the service elements which are in the bad category, including the cost / tariff element. Efforts to improve the performance of Central Lampung Regency Government can be done by prioritizing programs / activities on the lowest element of the IKM value. In addition, synergy between agencies is needed to improve the service performance of the Central Lampung Regency Government.

\section{References}

[1] Badudu dan Zain, 2000, Kamus Umum Bahasa Indonesia, Pustaka Sinar Harapan, Jakarta

[2] H. M. Busrizalti, 2013, Hukum Pemda Otonomi Daerah dan Implikasinya, Total Media, Yogyakarta

[3] Hambali, 2015, Ilmu Administrasi Birokrasi Publik, Yayasan Kodama, Yogyakarta,

[4] Hardiansyah, 2011, Kualitas Pelayanan Publik, Gava Media, Yogyakarta

[5] Istianto, Bambang, 2009, Manajemen Pemerintahan Dalam Persepektif Pelayanan Publik, Mitra Wacana Media, Jakarta 
[6] Tjiptoherijanto, Prijono. "Reform of the Indonesian Civil Service: Looking for Quality." Economics World 6, no. 6 (2018): 433-443

[7] Abd Kadir, H. and Rajindra, R., 2018. PUBLIC SERVICE ANALYSIS ON IMPROVING COMMUNITY SATISFACTION. Jurnal Sinar Manajemen, 5(1), pp.69-73

[8] Khorida, P., Hadidah, I.S. and Damayanti, N.A., 2019. Community Satisfaction Index as an Evaluation of Health Services Quality. Indian Journal of Public Health Research \& Development, 10(2)

[9] Savira, Evi Maya, and Krismiyati Tasrin. "Involvement of local wisdom as a value and an instrument for internalization of public service innovation." BISNIS \& BIROKRASI: Jurnal Ilmu Administrasi dan Organisasi 24, no. 1 (2018)

[10] Robi, C.K., Rudy, R., Rudi, W. and Chaidir, A., 2018. Analysis of Public Service Survey in West Lampung. Analysis of Public Service Survey in West Lampung, 1(1), pp.292-304

[11] Josep Riwu Kaho, 1996, Mekanime Pengontrolan Dalam Hubungan Pemerintah Pusat Dan Daerah,Bina Aksara, Jakarta

[12] Mardiasmo, 2002, Akuntansi Sektor Publik, Suatu Pengantar, Erlangga, Yogyakarta

[13] Mendelsohn. James D, 1998, Don't measure customer satisfaction - manage it, Marketing News, Oct, 26, 32, 22, ABI/INFORM Global

[14] Mote. F, 2008, Analisis Indeks Kepuasan Masyarakat (IKM) Terhadap Pelayanan Publik Di Puskesmas Ngesrep, Semarang, Tesis, Universitas Diponegoro, Semarang

[15] Rahmayanty. Nina, 2010, manajemen pelayanan prima, Edisi Pertama, Graha Ilmu, Yogyakarta

[16] Sinambela, Litjan Poltak, dkk, 2011, Reformasi Pelayanan Publik, Teori, Kebijakan, dan Implementasi, PT Bumi Aksara, Jakarta

[17] Sugiyono, 2010, Metode Penelitian Administrasi, Pendekatan Kuantitatif, Kualitatif, dan R\&D, Alfabeta, Bandung

[18] The Liang Gie, Pertumbuhan Daerah Pemerintahan Daerah di Negara Kesatuan Republik Indonesia, Gunung Agung, Jakarta

[19] Waluyo, 2007, Manajemen Publik, Mandar Maju, Sumedang

[20] Undang-Undang Nomor 25 Tahun 2009 tentang Pelayanan Publik (Lembaran Negara Republik Indonesia Tahun 2009 Nomor 112, Tambahan Lembaran Negara Republik Indonesia Nomor 5038)

[21] Undang - Undang Nomor 23 Tahun 2014 tentang Pemerintahan Daerah

[22] Peraturan Pemerintah Nomor 96 Tahun 2012 tentang Pelaksanaan Undang Undang Nomor 25 Tahun 2009 tentang Pelayanan Publik (Lembaran Negara Republik Indonesia Tahun 2012 Nomor 215)

[23] Peraturan Menteri Pendayagunaan Aparatur Negara Dan Reformasi Birokrasi Republik Indonesia Nomor 14 Tahun 2017 Tentang Pedoman Penyusunan Survei Kepuasan Masyarakat Unit Penyelenggara Pelayanan Publik 